\title{
Academic Quality Assurance in the Colleges of Education: Challenges and Ways Forward for Future Development
}

\author{
Sele Sylvester Ebisine \\ Department of Mathematics, Colleges of Education, Warri, Nigeria \\ Phone No.: 08032716836 \\ E-mail: ebisineselesylvester@yahoo.com
}

\begin{abstract}
Colleges of education encompassed the production of professional teachers who are equipped with skills and methodologies of teaching in our primary and junior secondary levels of education in Nigeria. Essentially, colleges of education are to provide full-time courses in teaching, instruction and training and to conduct courses in education for qualified teachers. In order to achieve this objective, academic quality assurance is required. Against this background, the paper examines academic quality assurance and determines the general opinion on academic quality assurance in the colleges of education. It equally highlights some challenges to academic quality assurance in the colleges of education. Finally, the paper proffered some solution required by the colleges of education to stamp out the challenges for future development. Finally, the paper recommends that there should be regular monitoring and evaluation of all the units concern with the certification of colleges of education graduates.
\end{abstract}

Keywords: Academics; Quality Assurance; Colleges of Education; Challenges and Developmen

\section{INTRODUCTION}

Tertiary education has basically statutory functions of producing middle and high-level manpower for national development. This is in addition to providing intellectual training in the basic sciences and the liberal arts. Specifically, tertiary education, according to the National Policy on Education (2004), has the following goals to:

a. contribute to national development through high level relevant manpower training;

b. develop and inculcate proper values for the survival of individual and society;

c. develop the intellectual capability of individuals to understand and appreciate their local and external environments;

d. acquire both physical and intellectual skills which will enable individuals to be selfreliant and useful members of the society;

e. promote and encourage scholarship and community service;

f. forge and cement national unity; and

g. promote national and international understanding and interaction.

The above goals are to be pursued through teaching, research and development, virile staff development programmes, generation and dissemination of knowledge, a variety of modes of programmes including full-time, part-time, block-release, day-release, sandwich, etc. 
colleges of education, both conventional and specialized (colleges of education, technical) are among the various categories of tertiary institutions in Nigeria.

Essentially, colleges of education are to provide full-time courses in teaching, instruction and training and to conduct courses in education for qualified teachers. Anikweze (2001) noted that colleges of education were to produce highly qualified non-graduate professional teachers for the primary and junior secondary level of education in Nigeria. To ensure colleges of education products attain the broad goals of tertiary education, as well as, ensure quality in the preparation of teachers, relevance and professionalism there is need for academic quality assurance. Academic quality assurance implies that the products of colleges of education are of high quality and ensure the right person is awarded the right grade at the successful completion of a programme. The point being made here is that the issue of academic quality assurance to ensure credibility of certification is essential in teacher production. Thus, where a deviation occurs, quality required will no longer be assured.

Furthermore, the higher the quality of teachers churned out by the colleges of education, the faster the rate of growth and development and achievement of the Universal Basic Education (UBE) goals as well as Millennium Development Goals (MDGs). On the contrary lower quality may impact negatively on development. Apparently, there are factors responsible for low academic quality assurance and such factors are challenges that must be addressed to ensure desired condition that enhanced academic quality that can result in growth and future development. Consequently, the aims of the paper are:

- examine what academic quality assurance entails;

- determine what the general opinions is, on the academic quality assurance in colleges of education;

- discuss some challenges to academic quality assurance in colleges of education;

- suggest the ways forward for future development.

\section{ACADEMIC QUALITY ASSURANCE: WHAT IS IT?}

Academic quality assurance can be referred to as ensuring that all the processes involved in the instruction of students remain standardized at all times. Okebukola (2004) presents academic quality assurance as a process of continuous improvement in the quality of teaching and learning activities which will be achieved via pathways of employing mechanisms internal and external to the system. It is ensuring that at least the provision of the Minimum Academic Standards (MAS) documents are attained, maintained and enhanced (Omoregie, 2005). To this end, the enabling decree establishing the National Commission for Colleges of Education (NCCE) mandates it to, among other functions; make recommendation on the National Policy necessary for full development of teacher education and the training of teachers; lay down minimum standards for all programmes of teacher education and accredit their certificate and other academic awards. Admittedly, the minimum academic standards specify the performance criteria which should be complied with by colleges of education in the different disciplines. Full compliance with the approved criteria for a particular academic programme leads to the academic programmes being given full accreditation. In this respect, it implies that for an individual to acquire a certificate in a college of education he/she must meet the minimum standards of the institution before issuance of certificate.

Therefore, academic quality assurance demands that an appropriate monitoring system be in place so that requisite data for judging quality can be obtained (Afemikhe, 2007). 
According to him, quality assurance involves all actions that are necessary to provide adequate confidence that a product or service will satisfy given requirements for quality. He further maintained that the mission of quality assurance activities is to: improve quality through guidelines, promote wide deployment and proper implementation of specification, communicate and design effective processes to achieve goals. In essence, quality in the colleges of education in Nigeria is multi-dimensional concept which should embrace all its functions and activities: teaching and academic programmes, research and scholarship, staffing, students, building, facilities, equipment, services to community and academic environment (UNESCO as cited in Omoregie, 2005) as depicted in the model below:

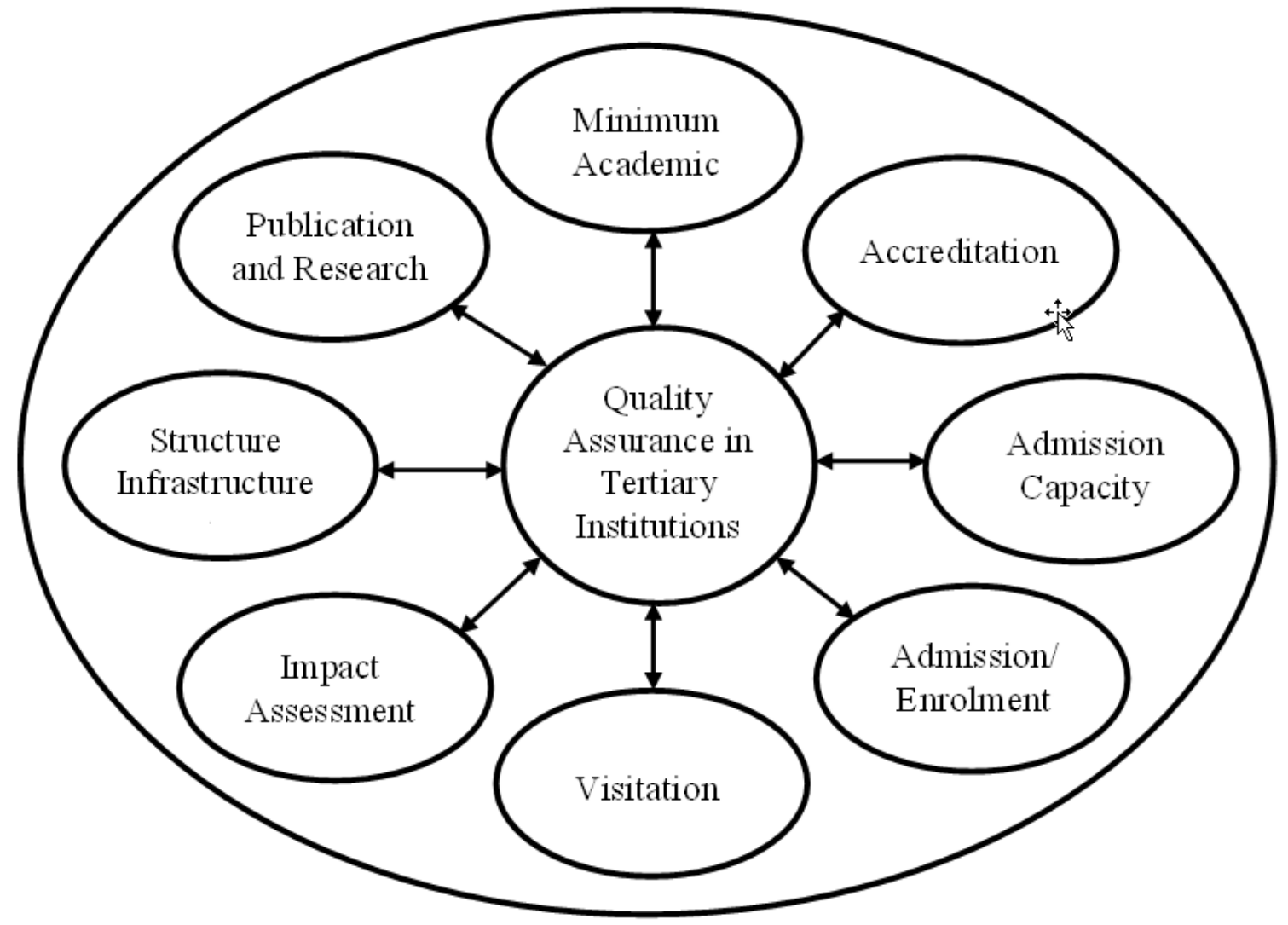

Fig. 1. Quality assurance drivers in tertiary institutions in Nigeria

Source: Adopted from Adedipo (2007) University quality assurance, funding strategy and task allocation.

\section{OPINIONS ON ACADEMIC QUALITY ASSURANCE IN COLLEGES OF EDUCATION}

First, there is the need to look at Aghenta (1991) contention on quality education. He was of the opinion tha ${ }^{+}$the quality of education in Nigeria appears to be elusive because, the following five inputs into learning are not of the right quality. These are:

- students (their capacity and motivation to learn),

- the subject to be learned,

- the teachers who know and can teach the subject, 
- time for learning,

- requisite tools for teaching and learning.

A Close look at our colleges of education indicates that most of the certified products lack acceptable level of competence in their area of specialization. Ifedili (2002) asserted that many departments in various Nigeria educational system are producing not so qualified graduates which have a negative chain effect in the economic, social and political development of the country. According to Ade-Ajayi (2002) World Bank Funded Research by the Nigerian Institute for Social and Economic Research (NISER) reported that Nigerian graduates are below standard in the acquisition of language analytical and technical skills. Other verdicts are no less frustrating. Nwamaradi and Nzeluim (1995) are of the opinion that inadequate preparation of teachers and low status of teaching profession among others contributes to low quality education. The inadequately prepared teachers will inexorably result in developing a society of inadequacies. Oni and Dabalen (2000) reported that academic standards have fallen drastically over the past few decade. Thus, Obayan (2002) remarks that what exist as higher education is not as high as it ought to be.

There seems to be a general pattern of academic quality failure in colleges of education in Nigeria. In order to have quality teachers, Harris (1992) is of the opinion that teacher production in the colleges of education should be based on a sound philosophy and on such rationale that should guarantee the acquisition of necessary knowledge components and professional skills which would enable pre-service would-be teachers to benefit from schooling and become better teachers. This expectation is perceived as critical to the survival of the various disciplines in the curriculum of education. According to Obayan (2002) what higher education (inclusive of colleges of education) should do for Nigeria is to provide her work critical mass of person with analytical power, communicative skills, problem solving ability, team spirit, creative, versatility and lifelong learning skills who will act as catalyst to national development.

Adjudged from the above consideration, the general feeling is that colleges of education are failing us in the production of quality teachers. The most potent likely reason is that there are challenges to academic quality assurance in the colleges of education resulting in steady decline in quality/standard. Some of these challenges are discussed below.

\section{CHALLENGES OF ACADEMIC QUALITY ASSURANCE IN COLLEGES OF EDUCATION}

The problem of low academic quality assurance is a function of a number of factors such as population growth, poor facilities and equipment, examination malpractices, poor staffing, poor funding, corruption, and quality of students.

Population Growth: Currently, there is student population explosion in Federal and State colleges of education due to increase in enrolment without the required or expansion of facilities. The implication of population explosion is that classrooms are over-crowded while laboratories and other learning materials are grossly inadequate because of insufficient funding (Omoregie, 2005). Population explosion means also that there are no enough chairs, desks, tables, water and electricity, no space for teachers and students to go round for interaction; there is overcrowding everywhere leading to restiveness and indiscipline (Akpochafo and Filho, 2008). This has its consequences for standards and quality in form of low growth and productivity of students and graduates of the colleges of education. 
Poor Facilities and Equipment: This is manifest in inadequate and poor state of classroom, offices, laboratories, hostels and libraries. The provision of the relevant educational facilities and equipment is vital in the provision of quality educational services to all students in the colleges of education. However, the poor state of facilities and equipment has been a major challenge to academic quality assurance in the college of education.

Examination Malpractice: Examination malpractice has undergone various forms and sophistication. Common examples are impersonation, bringing prepared notes and textbooks into the examination hall, bringing information on items of clothing, palm and currency notes, bribing invigilators and supervisors, etc. Examination malpractice threatens any academic and professional system. Examination malpractice has implication on academic quality and standard as mediocre are produced from any educational system that is fraught with examination malpractice (Osagiede, 2005).

Poor Staffing: The success of any education system depends to a very large extent on the supply of teachers in terms of quantity and quality. According to Utulu as cited in Akpochafo and Filho (2008) teachers are the quality indicators in the educational process. They represent a key input of a highly skilled labour resource which combined with the education plant and its allied services, produces educated or at least schooled individuals. But the colleges of education are face with problem of shortage of highly experienced academic staff. For instance, ratios by discipline are far from encouraging especially in the humanities and some science-based disciplines (Omoregie, 2005). The problem of quantity and quality academic staff has serious implications for academic quality assurance and credentialing. As noted by Akpochafo and Filho (2008) the shortage of staff (both in quantity and quality) means high student-lecturer ratio which will impact on the teaching-learning process. According to them, individualized attention is hard to achieve, it encouraged memorization, examination malpractice and result in the neglect of inculcation of analytical and problem solving skills needed for life. The summary is that the expected quality and standard are not being meant.

Poor Funding: A well-structured funding arrangement is imperative for meeting the cost of providing adequate educational service in colleges of education. However, inadequate funding affects the provision of facilities and the recruitment of the desired manpower to implement the programmes that have been developed. This in turn affects the academic delivery in the colleges of education resulting in what Yaqub (2002) called "a dull intellectual atmosphere". Anavberokhai (2007) averred the poor funding affects proper planning and implementation of policies and programmes, as well as, lower productivity. The UNESCO has recommended a standard budget allocation to educational sector to stand as $26 \%$. The Nigerian government has since 1999 been spending less on education. From the allocation of $11.2 \%$ in 1999, the figure fell to $8.36 \%$ in 2000 and $7.0 \%$ in 2001. In 2002, the figure was $5.9 \%$ and $1.83 \%$ in 2003 . The reduced spending has impacted negatively on the system as basic necessities for teaching and research are lacking in both federal and state colleges of education. Jaiyeoba and Atanda (2005) remarked that fund is crucial in facilities acquisition, staff development (to cater for the enrolment increase) and for policy implementation. In the face of acute shortage of funds, other inputs suffer setback, which in turn influence the level of quality obtainable. To this end, poor funding has the following implications for academic quality assurance:

- inability to recruit and retain qualified staff;

- inadequately funded research activities;

- inability to meet the welfare and academic needs of staff and students resulting in strikes and closure of institutions; 
- general frustration of staff leading to brain drain;

- collapse of facilities and equipment;

- emergence of unedifying academic situation and the erosion of time-honoured standards academically and morally;

- the jettisoning of procedures and the enthronement of a dull intellectual atmosphere (Yaqub, 2002).

In effect, poor facilities, and other learning materials, due to poor funding impede academic quality assurance.

Corruption: Embezzlement, misappropriation and diversion of the scarce funds meant for educational purposes further impoverish the sector (Anavberokhai, 2007). The implication is that there can hardly be any meaningful implementation of policy, acquisition of facilities and libraries which are vital to effective teaching and research.

Quality of Students: These days, the quality of fresh men admitted into the system is low. This is because their preparation at the primary and secondary levels were poor and many of them passed their examination by relying heavily on examination malpractice (Akpochafo and Filho, 2008). According to them, they (students) lack the culture of scholarship and hard work. Many go into lecture halls without textbooks and even pens. A good number of them, they stated, recorded less than $50 \%$ attendance at lectures and default in assignments. Students now see the acquisition of credentials/certificate as a do or die affair, even if it means attaining the certificate not on the basis of learning. As noticed by Akpochafo and Filho (2008), students in Nigeria higher institutions are not there for serious and committed academics, they shun the strain and rigour associated with higher education. They further maintained that it becomes difficult to get students to learn, to investigate, to research to engage in independent study. The bottom line is that the quality and standard of students are no longer assured.

\section{THE WAYS FORWARD FOR FUTURE DEVELOPMENT}

The following suggestions are put forward as means of overcoming the challenges, which in turn can improve future development:

Improved Facilities and Equipment: If improvements are to manifest in the quality and standard in the service and products of colleges of education, it is imperative that colleges should be adequately equipped and staffed so that they can carry out meaningful teaching and learning. Adequate facilities are very vital to the successful training and certification of products.

Eradication of Examination Malpractice: Concrete efforts should be geared towards value re-orientation as regards examination malpractice. In this regard, there is need to put in place a regular internal examination monitoring committee comprising of academic and non-academic staff of the college of education to monitor the conduct of all examinations and bring those who engaged in examination malpractice to book. Also, there should be creation of favourable environments for studies in colleges of education.

Improved Funding: Government should have the political will to determine how education in Nigeria should be funded and simply with its decisions on funding parameters. Thus, the proposed $26 \%$ of Federal Government's budgetary allocation to education as suggested by UNESCO should be approved. The Delta State government is doing a lot in this regard by 
granting subvention and promptly releasing fund to operate the colleges of education. Also, since education is capital intensive enterprise, guaranteed alternative sources of funding need to be identified to ensure the required facilities and equipment are put in place for effective teaching and learning in colleges of education. Besides, there is need for some integrity on the party of school management. Funds for academic purpose must only be used for their original purposes and never diverted or misappropriated. There is need for improved funding because promotion of high and improved quality and standard in college of education are often constrained by underfunding and inadequate financial resources.

Staff Development and Welfare: The quality and quantity of staffs needed to be raised. On its part, government should make the job of lecturing more attractive - better pay, funds for research and improved work environment (Akpochafo and Filho, 2008). Afemikhe (2007) advised colleges of education authorities to emphasize on teachers training and re-training to acquaint them with development in assessment practices that can provide more valid and reliable scores. One agrees with these suggestions and urges colleges of education to encourage staff to attend seminars, workshops and conferences. Effective teaching cannot be achieved without sound knowledge of new technologies of teaching.

External Academic Quality Assurance Mechanism: The adoption of benchmarks by NCCE to evaluate and maintain quality in all the colleges of education in Nigeria.

Internal Academic Quality Assurance Mechanism: The required setting up academic quality assurance unit in colleges of education to monitor and evaluate teaching-learning process. Omoregie (2005) listed the duties of the academic quality assurance unit to include the following:

- supervision of curriculum design, content and organization;

- supervision of curriculum implementation (course by course) - what portion of a 16 weeks semester is used for actual teaching;

- students class attendance (register of attendance must be kept);

- student progression and achievements including attrition/dropout rate;

- student support, and guidance and counseling;

- periodic assessment of human and material resources available to each programme;

- feedback to all levels following data analysis to facilitate continuous improvement in quality;

- continuous interface with Quality Assurance Agency and professional bodies to keep abreast with latest information;

- tracking of the graduates for feed-back from employers.

\section{CONCLUSION}

Education is regarded the world over as a very important tool for development. Through colleges of education, one is prepared to adapt to social, political, technological and economic challenges. Academic quality assurance is the way to ensure that students acquire the needed skills and talent in order to face the listed challenges of life. Ensuring quality and standard in the colleges means eliminating the identified challenges to academic quality assurance. Failure to overcome these challenges can continue to make the colleges of education products of low quality. 


\section{RECOMMENDATIONS}

1. There is need to overhaul the system to evaluate the extent low quality standards have infiltrated the colleges of education.

2. Firm enforcement of various strategies to stamp out examination malpractice without fear or favour.

3. Motivation of staff to encourage enhanced productivity in the colleges of education.

4. Regular monitoring and evaluation of all the units concern with the certification of colleges of education graduates.

5. Regular in-service programmes, workshops, seminars and conferences for both academic and non-academic staff to abreast them of new development in their discipline.

\section{References}

[1] Ade-Ajayi J. F. (2002). Paths to the sustainability of higher education. SSAN; Abuja; $1-11$.

[2] Adedipo N. O. (2007). University quality assurance, funding strategy and task allocation. A paper presented at the workshop and tertiary education financing. University of Lagos. April 23-24.

[3] Afemikhe O. A. (2007). Quality assurance in school-based assessment practices and monitoring. A lead paper presented at the $9^{\text {th }}$ Annual Conference of the National Association of Evaluators and Researchers (NAERE) held at Olabisi Onabanjo University, Ago-Iwoye, Ogun State, Nigeria between December 3-6, 2007.

[4] Aghenta A. (1991). Educational planning a turning point in education and development in Nigeria. Inaugural Lecture Series 58, University of Benin, Benin City.

[5] Akpochafo W. A., Filho W. L. (2007). "An overview of the barriers to curriculum implementation in Nigerian universities ". International Journal of Continuing Engineering Education and Life-Long Learning.

[6] Anavberokhai M. O. (2007). Studies in Education 9(1-2) (2007) 63-67.

[7] Federal Republic of Nigeria (2004). National Policy on Education. Lagos: NERDC Press.

[8] Harris K. (1992). Teacher and classes: A Marxist analysis. London: Routledge \& Kegan Publication.

[9] Ifedili C. (2002). "Time utilization and goal setting by the students in the University of Benin”. International Journal of Educational Planning and Administration.

[10] Jaiyeoba A. O., Atanda A. I. (2005). "Quality sustenance in Nigeria educational system: Challenges to government”. In G. O. Akpa, S. U. Udoh \& E. O. Fagbamiye (eds). Deregulating the provision and management of education in Nigeria. Jos: The Nigerian Association for Educational Administration and Planning (NAEAP). 
[11] Nwamaradi A. I., Uzelum A. O. (1995). Strategies for improving the practical content in technology education in Nigeria. A paper presented at the $8^{\text {th }}$ Annual National Conference of Nigerian Association of Teachers of Technology (NATT) on production approach to the teaching of concepts in technology, held at Federal College of Education (Technical). Women. Guseau, Sokoto, November 21-24.

[12] Obanya P. (2002). Revitalizing education in Africa. Lagos: Stirling-Horden Publishers.

[13] Okebukola P. (2004). "Quality assurance in Nigerian universities". Nigeria University System Chronicle. A Quarterly Publication of National Universities Commission, 12 (1).

[14] Omoregie N., Studies in Education 8 (2005) 128-134.

[15] Oni B., Dabalen A. (2000). Labour marked prospects for university graduates in Nigeria; Mimeograph Report of World Bank, NISER.

[16] Osagiede F. I., Studies in Education 8 (2005) 77-80.

[17] Yaqub N. (2002). Higher education in Nigeria in perspective. Paths to the sustainability of higher education in Nigeria, SSAN, Abuja; 12-20. 